\title{
Sideroblastic anaemia associated with lincomycin therapy
}

\author{
G. KOKKINI* \\ M.D.
}

E. TSIANOS*

M.D.

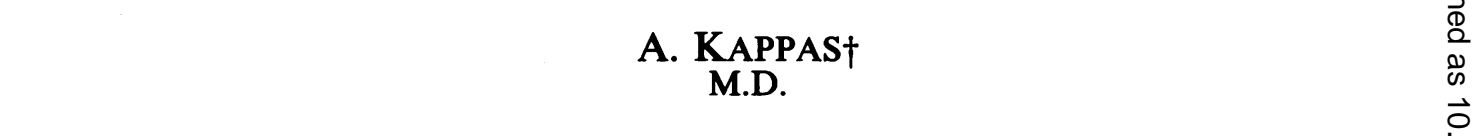

*Department of Medicine and †Department of Surgery, School of Medicine, University of Ioannina, Ioannina Greece

\begin{abstract}
Summary
Sideroblastic anaemia developed after lincomycin therapy in a 58-year-old woman. The anaemia proved completely reversible after termination of lincomycin therapy and the introduction of pyridoxine. The patient also had pseudomembranous enterocolitis, a well-known side effect of lincomycin.
\end{abstract}

KEY WORDS: sideroblastic anaemia, lincomycin therapy, ring sideroblasts, pseudomembranous enterocolitis.

\section{Introduction}

Sideroblastic anaemia was recognized as a distinct entity 22 years ago. The classification of sideroblastic anaemia into hereditary, idiopathic acquired and secondary is now widely accepted. Recently, the difference between sideroblastic anaemia and 'sideroblastic change' has been emphasized, in order to avoid diagnostic confusion (Bateman, 1980). We report a case of secondary sideroblastic anaemia after lincomycin therapy, an association that has not been previously described.

\section{Case report}

A 58-year-old woman was admitted complaining of general malaise and diarrhoea. Seventeen days previously, she had been admitted to another hospital because of an injury to the left lower extremity where she initially had a surgical cleansing of the wound. Two days later lincomycin, $300 \mathrm{mg} 4$ times a day, was administered. After 8 days on lincomycin, she started to have diarrhoea, 3-4 times a day with watery smelly stools. Lincomycin was discontinued, but the patient's condition deteriorated and she was referred to our department.

There was no anaemia in either the patient's past history or family history and she did not drink alcohol.
On admission, the patient appeared acutely 911 , dehydrated but afebrile. Abdominal distension of prominent.

Investigations showed haematocrit $0 \cdot 34$; white $\stackrel{\circ}{\mathrm{e}}$ ll count $27.5 \times 10^{9} /$ litre; granulocytes $23.4 \times 10^{9} /$ litrre; shift to the left and toxic granules in the granulocytes: erythrocyte sedimentation rate $42 \mathrm{~mm} / \mathrm{hr}$ (Westergren); total serum proteins $\mathbf{4 2} \mathrm{g} /$ litre. The remain routine blood and urine chemistry was nornial. Faecal occult blood positive. Investigations for of atasites and stool cultures for aerobic micro-orga is were negative. Findings on sigmoidoscopy an $\overline{f b a r}$ ium enema were suggestive of pseudomembranous enterocolitis.

Supportive care with fluids, electrolytes and al $5 \mathrm{u}-$ min was instituted.

On the fourth day after admission, the haematocrit was found at a lower level $(0 \cdot 31)$. The peripheुal blood smear showed a small population of hypochromic cells, moderate anisocytosis and poikilocytosis. Bone marrow aspiration was therefore performed and showed hypercellular marrow with granulocye: erythroid ratio $(G: E)=3: 1$; myelopoiesis maturation arrest at the levels of promyelocyte and myelocyse; vacuoles in the granulocytes precursors; erythroid line with a few megaloblastic changes. Stain for iron of bone marrow aspirate revealed abundance of iron in the reticuloendothelial cells and in nucleated fed blood cells, $30 \%$ of which were typical 'ring sideroblasts'. Methicillin was administered from the 4thito 9th day after admission and then vancomycin $\bar{\Omega} 2$ g/day) for 7 days.

On the 13th day in the hospital, haematocrit 0.22 and a dimorphic population in the periphetal blood smear was easily seen; repeat bone marrow aspiration showed no maturation arrest or vacuolated precursors in myeloid line, hypercellular erythroid line $(G: E=1: 1)$ and typical 'ring sideroblasts' 50\% of the nucleated red cells (Fig. 1). Serum iron was $₫ 8$ 


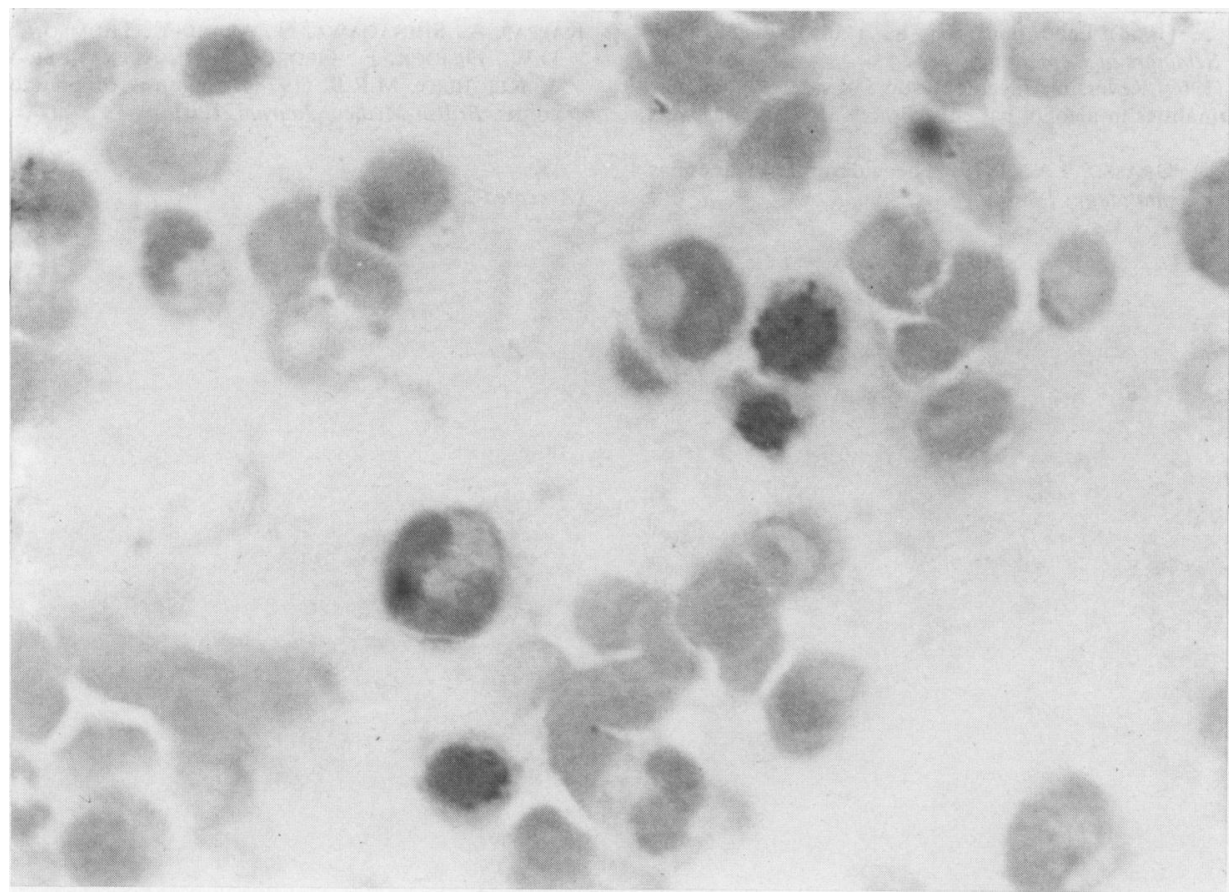

FIG. 1. Two 'ring sideroblasts' in the upper-middle field $(\times 4270)$.

$\mu \mathrm{mol} /$ litre and serum ferritin levels were $390 \mu \mathrm{g} / \mathrm{litre}$; serum lead levels were $170 \mu \mathrm{g} /$ litre. Sideroblastic anaemia was diagnosed. Two whole blood units were transfused and pyridoxine, $750 \mathrm{mg} /$ day, was started.

The patient's general condition improved progressively as time went on, no 'ring sideroblasts' were demonstrated in bone marrow aspiration performed on the 47th day and she was discharged on the 55th day after admission. Four months after her initial examination, no abnormal findings were detected in blood (haematocrit $0 \cdot 43$ ), bone marrow aspiration, $X$ ray of small bowel, barium enema examination, sigmoidoscopy and liver biopsy.

\section{Discussion}

This case fulfills all the criteria of sideroblastic anaemia: dimorphic population of red blood cells in the blood smear, erythroid hyperplasia in the bone marrow and typical 'ring sideroblasts' more than 25\% of nucleated red cells (Bateman, 1980). A dimorphic population was not clearly apparent during the first 12 hospital days, probably because of the small number of affected red cells initially. In the first bone marrow aspiration, erythroid hyperplasia was probably obscured by the concomitant myeloid hyperplasia because of the bowel infection, but it was apparent in the 2 nd bone marrow aspiration when the white cell count had returned to normal. The fact that the patient had a history of oral lincomycin therapy, and no other drug, made us attribute the sideroblastic anaemia to lincomycin. It is known that sideroblastic anaemia is associated with exposure to lead (Goldberg, 1968), alcohol (Hines, 1969) and several drugs such as isoniazid (Hines and Grasso, 1970), and chloramphenicol (Beck, Ziegler and Schmid, 1967). Sideroblastic anaemia associated with lincomycin therapy has not previously been reported.

Our patient suffered from pseudomembranous enterocolitis which was attributed to lincomycin (Kappas et al., 1978; Editorial, 1978). An alternative explanation, however unusual, could be that sideroblastic anaemia was associated with the colon inflammation. 'Sideroblastic change' is a feature of many preleukaemic and leukaemic conditions but sideroblastic anaemia or 'sideroblastic change' have not been associated with inflammatory diseases.

\section{References}

Bateman, C.J. (1980) Sideroblastic anemia. Archives of Internal Medicine, 140, 1278.

BECK, E.A., ZIEGLER, G. \& SCHMID, R. (1967) Reversible sideroblastic anemia caused by chloramphenicol. Acta Hematologica, 38, 1. EDITORIAL (1978) Antibiotic-associated colitis. A progress report. British Medical Journal, 1, 669. 
GOLDBERG, A. (1968) Lead poisoning as a disorder of heme synthesis. Seminars in Hematology, 4, 424.

HINES, J.D. (1969) Reversible megaloblastic and sideroblastic marrow abnormalities in alcohol patients. British Medical Journal, 1, 87.

Hines, J.D. \& Grasso, J.A. (1970) The sideroblastic anemias. Seminars in Hematology, 7, 86.
Kappas, A., Shinagawa, N., Arabi, Y., Thomson, H., Burdon, D.W., Dimock, F., George, R.H., AleXANDER-Williams $\mathrm{S}$. \& KEIGHLEY, M.R.B. (1978) Diagnosis of pseudomembranous colitis. British Medical Journal, 1, 675.

(Accepted 2 February 1983) 